\title{
HYDRATING CHARACTERISTICS OF MODIFIED PORTLAND WITH Ba-BEARING SULPHOALUMINATE MINERALS
}

\author{
GONG CHENCHEN, "XIN JIBAO, WANG SHOUDE, LU LINGCHAO
}

\author{
Shandong provincial key Laboratory of preparation and measurement of building materials, \\ University of Jinan, Jinan 250022, China \\ \#E-mail: 1205070875@qq.com
}

Submitted October 8, 2015; accepted January 20, 2016

\begin{abstract}
Keywords: Modified Portland cement, Ba-bearing sulphoaluminate minerals, Hydrating characteristics
The hydrating characteristics of modified Portland cement with Ba-bearing sulphoaluminate minerals were studied in this paper. Scanning Electron Microscopy-Energy Dispersive Spectrometer (SEM-EDS), mercury intrusion porosimeter(MIP) and compressive strength were determined to characterize hydrating products and microstructure. Results show that basic physical properties of modified Portland cement with Ba-bearing sulphoaluminate minerals (SMPC) are similar with PC except the shorter setting time. Ettringite and $C-S-H$ are the main hydrating produces in SMPC, which is similar to Portland cement (PC). Because of volume expansion of ettringite, SMPC paste structure is denser than PC according to SEM-EDS analysis and the pore size and pore content of SMPC pastes was smaller especially for the harmful pores. Because sulfur aluminum barium calcium was a new early-strength mineral and parts of $\mathrm{BaO}$ went into the $\mathrm{C}_{2} \mathrm{~S}$ lattice and caused lattice distortion to enhance $C_{2} S$ hydration activity, the compressive strengths of SMPC grew faster and higher than PC.
\end{abstract}

\section{INTRODUCTION}

The manufacture of Portland cement (PC) not only consumes a vast amount of energy and high calcite but also produces undesirable $\mathrm{CO}_{2}$ emissions [1-3]. 0.97 tons of $\mathrm{CO}_{2}$ to produce per ton of $\mathrm{PC}$ are released into atmosphere: 0.54 tons of $\mathrm{CO}_{2}$ from decomposition of calcite in the kilns, and on average, 0.34 and 0.09 tons of $\mathrm{CO}_{2}$ from the burning of the fuel and electricity for the milling, respectively [4-6].

However, belite-sulphoaluminate cement is a new kind of binding materials, called a sort of environmentfriendly cement [7-8]. Alite, the main component of PC, is formed at the temperature of about $1450^{\circ} \mathrm{C}$. Belite is formed at about $1200^{\circ} \mathrm{C}$. Its sintering temperature is $100 \sim 150^{\circ} \mathrm{C}$ lower than $\mathrm{PC}$, which can save amounts of energy consumption. Further, it is more friable than PC due to higher porosity, which reduces the energy needed for grinding [9]. In addition, the manufacture of belitesulphoaluminate cement can make use of low-grade limestone and harmful industrial barium slag. These three facts may cause a reduction of 0.16 tons of $\mathrm{CO}_{2}$ to produce per ton of belite-sulphoaluminate cement. It is up to $16 \% \mathrm{CO}_{2}$ emission reduction compared to PC. Therefore, belite-sulphoaluminate cement has the obvious advantages over PC.

The most common formulation of belite-sulphoaluminate cements are $\mathrm{C}_{2} \mathrm{~S}, \mathrm{C}_{4} \mathrm{~A}_{3} \breve{\mathrm{S}}$ and $\mathrm{C}_{4} \mathrm{AF}$ [10-13]. It contains more than 50 wt. $\%$ of $\mathrm{C}_{2} \mathrm{~S}$, classified as belite-rich materials. In spite of the complexity of the hydration reactions, there is already a significant number of literature on the subject. Y.B. Pliego-Cuervo et al. reported that in $\mathrm{C}_{2} \mathrm{~S}-\mathrm{C}_{4} \mathrm{~A}_{3} \stackrel{\mathrm{S}}{-}-\mathrm{C}_{12} \mathrm{~A}_{7}-\mathrm{CA}$ system aluminate phases and $\mathrm{C}_{4} \mathrm{~A}_{3} \breve{\mathrm{S}}$ were responsible for the early strength development, while the $\mathrm{C}_{2} \mathrm{~S}$ provided good secondary hardening [14]. H. Li et al. reported some non-hydraulic phases accompanied by $\mathrm{C}_{4} \mathrm{~A}_{3} \check{\mathrm{S}}$, such as $\mathrm{C}_{2} \mathrm{AS}$ or $\mathrm{C}_{5} \mathrm{~S}_{2} \breve{\mathrm{S}}$. F.P. Glasser et al. studied the hydration reactions of the cement pastes at early stages at different curing temperatures. It was inducted that at present early cementing performance of belite-sulphoaluminate was not good enough to satisfy the requirement of wide engineer, especially compared to PC [15].

In this paper, modified Portland cement with sulphoaluminate minerals (SMPC) was designed to improve early cementitious property on the basis of saving energy. It contained $\mathrm{C}_{3} \mathrm{~S}, \mathrm{C}_{2} \mathrm{~S}, \mathrm{C}_{4} \mathrm{AF}, \mathrm{C}_{3} \mathrm{~A}, \mathrm{C}_{2.75} \mathrm{~B}_{1.25} \mathrm{~A}_{3} \check{\mathrm{S}}$ and $\mathrm{CaSO}_{4}$ as the main phases. $\mathrm{C}_{2.75} \mathrm{~B}_{1.25} \mathrm{~A}_{3} \stackrel{\mathrm{S}}{\mathrm{S}}$ could be synthesized at a lower temperature of $1350^{\circ} \mathrm{C}$ to $1400^{\circ} \mathrm{C}$, rather than the $1400^{\circ} \mathrm{C}$ to $1500^{\circ} \mathrm{C}$ of Portland cement clinker. And its decomposition temperature was more than $1400^{\circ} \mathrm{C}$, approximately $50^{\circ} \mathrm{C}$ higher than $\mathrm{C}_{4} \mathrm{~A} \breve{S}$. In theory, a chance was provided for $\mathrm{C}_{2.75} \mathrm{~B}_{1.25} \mathrm{~A}_{3} \mathrm{~S}$ to coexist with $\mathrm{C}_{3} \mathrm{~S}$ in the same system. In addition, the substitution of $\mathrm{Ba}^{2+}$ for $\mathrm{Ca}^{2+}$ could improve the performance of $\mathrm{C}_{4} \mathrm{~A}_{3} \check{\mathrm{S}}$ [16-19]. The Ba-bearing calcium sulphoaluminate mineral content of clinker and the $\mathrm{Ba}^{2+}$ ion content of the mineral contributed greatly to the cement characteristics, such as rapid hardening and early strength. In the series of Ba-bearing calcium 
sulphoaluminates, substitution of $1.25 \mathrm{~mol} \mathrm{Ba}^{2+}$ ions for $\mathrm{Ca}^{2+}$ ions provided the highest strength. $\mathrm{C}_{2.75} \mathrm{~B}_{1.25} \mathrm{~A}_{3} \breve{\mathrm{S}}$ was a good hydraulic binding mineral and had high early strength. However, so far, there had been few previous studies to improve cement manufacture and properties with $\mathrm{C}_{2.75} \mathrm{~B}_{1.25} \mathrm{~A}_{3} \check{\mathrm{S}}$. The aim of the present study was to investigate the possibility of coexistence of $\mathrm{C}_{2.75} \mathrm{~B}_{1.25} \mathrm{~A}_{3} \breve{\mathrm{S}}$ and $\mathrm{PC}$ clinker as well as hydrating characteristics of the new cementitious material, including analyses of physical and mechanical properties, hydration products and microstructure of hydrating pastes.

\section{EXPERIMENTAL}

\section{Raw material}

$\mathrm{CaCO}_{3}, \mathrm{SiO}_{2}, \mathrm{Al}_{2} \mathrm{O}_{3}, \mathrm{Fe}_{2} \mathrm{O}_{3}, \mathrm{BaSO}_{4}, \mathrm{BaCO}_{3}$ and $\mathrm{CaF}_{2}$ were pure chemical reagents. The fineness was below $6.3 \%$ (residue on $0.08 \mathrm{~mm}$ sieve). PC came from Shandong cement plant in China. Gypsum came from Zibo in China. The chemical compositions of PC and gypsum performed with the X-ray fluorescence (XRF-1700) analyzer were presented in Table 1.

\section{Preparing process of SMPC clinker}

All the raw materials were dried in an oven at $100^{\circ} \mathrm{C}$ for $4 \mathrm{~h}$ and ground to pass $0.08 \mathrm{~mm}$ sieve before batch compositions were made. The batch compositions were mixed thoroughly. After thorough homogenization, raw meals were nodulized to the size of approximately $15 \mathrm{~mm}$ diameter each. Nodules were dried in an oven at $100^{\circ} \mathrm{C}$ for $1 \mathrm{~h}$ before introducing into the furnace. The batch compositions were fired at $1380^{\circ} \mathrm{C}$. The sintering duration was $1.5 \mathrm{~h}$. Then SMPC clinker was obtained. The

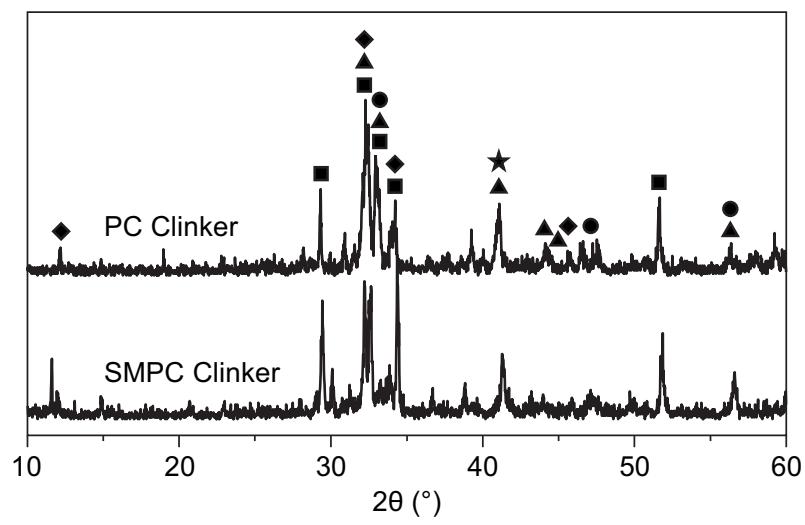

Figure 1. XRD patterns of clinkers. mineral composition of belite-barium calcium sulphoaluminate clinker designed in this paper was shown in Table 2. The fired clinker was relatively soft and friable, and easy to grind; consequently, the whole process results in considerable saving of energy.

XRD pattern of SMPC clinker was presented in Figure 1 . The primary minerals were $\mathrm{C}_{3} \mathrm{~S}, \mathrm{C}_{2} \mathrm{~S}, \mathrm{C}_{4} \mathrm{AF}, \mathrm{C}_{3} \mathrm{~A}$ and $\mathrm{C}_{2.75} \mathrm{~B}_{1.25} \mathrm{~A}_{3} \breve{\mathrm{S}}$, which was consistent with experimental program in Table 2.

$\mathrm{C}_{2.75} \mathrm{~B}_{1.25} \mathrm{~A}_{3} \breve{\mathrm{S}}$ was generated at $1350^{\circ} \mathrm{C}$ and decomposed at $1400^{\circ} \mathrm{C}$. Though sintering temperature of SMPC clinker in this paper was about $70^{\circ} \mathrm{C}$ lower than $\mathrm{PC}$ clinker, in the calcination process $\mathrm{SO}_{3}$ and $\mathrm{BaO}$ played the roles of mineralizers and fluxes, which, to a certain extent, could promote the synthesis of $\mathrm{C}_{3} \mathrm{~S}$. Therefore, as was shown in Figure $1, \mathrm{C}_{2.75} \mathrm{~B}_{1.25} \mathrm{~A}_{3} \breve{\mathrm{S}}$ could coexist with $\mathrm{C}_{3} \mathrm{~S}$ at $1380^{\circ} \mathrm{C}$.

Table 2. Mineral composition of SMPC clinker designed (wt.\%).

\begin{tabular}{cccccc}
\hline & $\mathrm{C}_{3} \mathrm{~S}$ & $\mathrm{C}_{2} \mathrm{~S}$ & $\mathrm{C}_{3} \mathrm{~A}$ & $\mathrm{C}_{4} \mathrm{AF}$ & $\mathrm{C}_{2.75} \mathrm{~B}_{1.25} \mathrm{~A}_{3} \mathrm{~S}$ \\
\hline SMPC clinker & 37.5 & 39.5 & 4.6 & 11.46 & 7 \\
\hline
\end{tabular}

\section{Experimental design}

The hydrationg reactions of SWPC can been described by the following set of Equation 1-6.

$$
\begin{aligned}
& \mathrm{C}_{3} \mathrm{~S}+\mathrm{nH} \rightarrow \mathrm{C}-\mathrm{S}-\mathrm{H}+(3-\mathrm{x}) \mathrm{CH} \\
& \mathrm{C}_{2} \mathrm{~S}+\mathrm{nH} \rightarrow \mathrm{C}-\mathrm{S}-\mathrm{H}+(2-\mathrm{x}) \mathrm{CH} \\
& 2 \mathrm{C}_{3} \mathrm{~A}+27 \mathrm{H} \rightarrow \mathrm{CAH}_{19}+\mathrm{C}_{4} \mathrm{AH}_{13} \\
& \mathrm{C}_{3} \mathrm{~A}+3 \mathrm{CS}^{\circ} \mathrm{H}_{2}+26 \mathrm{H} \rightarrow \mathrm{C}_{6} \mathrm{~A}_{3} \mathrm{H}_{32} \\
& \mathrm{C}_{4} \mathrm{AF}+4 \mathrm{CH}+22 \mathrm{H} \rightarrow 2 \mathrm{C}_{4}(\mathrm{~A}, \mathrm{~F}) \mathrm{H}_{13}
\end{aligned}
$$

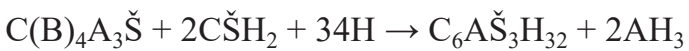

If $\mathrm{CS}_{2} \mathrm{H}_{2}$ is not adequate, because of $\mathrm{AH}_{3}$ and $\mathrm{C}_{4} \mathrm{AH}_{13}$, the paste will be flash setting; But if $\mathrm{CSS}_{2}$ is too much, the paste will retard. So $\mathrm{CS}_{\mathrm{S}}{ }_{2}$ content must be proper.

Assuming $\mathrm{CŠH}_{2}$ content is enough, full hydrating reactions of $\mathrm{C}_{3} \mathrm{~A}$ and $\mathrm{C}(\mathrm{B})_{4} \mathrm{~A}_{3} \breve{\mathrm{S}}$ are given as:

$$
\begin{gathered}
\mathrm{C}(\mathrm{B})_{4} \mathrm{~A}_{3} \check{\mathrm{S}}+8 \mathrm{C} \check{\mathrm{S}} \mathrm{H}_{2}+6 \mathrm{CH}+74 \mathrm{H} \rightarrow 3 \mathrm{C}_{6} \mathrm{AS}_{3} \mathrm{H}_{32} \\
\mathrm{C}_{3} \mathrm{~A}+3 \mathrm{C} \check{S} \mathrm{H}_{2}+26 \mathrm{H} \rightarrow \mathrm{C}_{6} \mathrm{AS}_{3} \mathrm{H}_{32}
\end{gathered}
$$

\begin{tabular}{|c|c|c|c|c|c|c|c|c|c|c|c|}
\hline \multirow{2}{*}{ Sample } & \multicolumn{7}{|c|}{ Chemical compositions } & \multicolumn{4}{|c|}{ Mineral composition } \\
\hline & Loss & $\mathrm{SiO}_{2}$ & $\mathrm{Al}_{2} \mathrm{O}_{3}$ & $\mathrm{Fe}_{2} \mathrm{O}_{3}$ & $\mathrm{CaO}$ & $\mathrm{MgO}$ & $\mathrm{SO}_{3}$ & $\mathrm{C}_{3} \mathrm{~S}$ & $\mathrm{C}_{2} \mathrm{~S}$ & $\mathrm{C}_{3} \mathrm{~A}$ & $\mathrm{C}_{4} \mathrm{AF}$ \\
\hline PC clinker & 3.21 & 21.37 & 5.68 & 3.59 & 61.03 & 1.3 & 0.8 & 54.3 & 21.9 & 7.04 & 10.0 \\
\hline
\end{tabular}

It can be calculated that $7 \mathrm{~g}$ of $\mathrm{C}(\mathrm{B})_{4} \mathrm{~A}_{3} \check{\mathrm{S}}$ consumes $7 \times(136.14 \times 8) / 731.79=10.42 \mathrm{~g} \mathrm{CS}$ per $100 \mathrm{~g}$ of SWPC clinker. Similarly, using Equation 4, $4.6 \mathrm{~g}$ $\mathrm{C}_{3} \mathrm{~A}$ of consumes $4.6 \times(136.14 \times 3) / 270.2=6.95 \mathrm{~g} \mathrm{CS}$

Table 1. Chemical compositions of PC clinker (wt. \%). 
per $100 \mathrm{~g}$ of SWPC clinker. So, full hydrating of $\mathrm{C}_{3} \mathrm{~A}$ and $\mathrm{C}(\mathrm{B}){ }_{4} \mathrm{~A}_{3} \breve{\mathrm{S}}$ consumes $17.37 \mathrm{CS}$ per $100 \mathrm{~g}$ of SWPC clinker.

If $\mathrm{CS}$ run out before $\mathrm{C}_{3} \mathrm{~A}$ completely hydrated, $\mathrm{C}_{6} \mathrm{AS}_{3} \mathrm{H}_{32}$ react with $\mathrm{C}_{3} \mathrm{~A}$ into $\mathrm{Afm}$, shown as Equation 9.

$$
2 \mathrm{C}_{3} \mathrm{~A}+\mathrm{C}_{6} \mathrm{AS}_{3} \mathrm{H}_{32}+4 \mathrm{H} \rightarrow 3\left(\mathrm{C}_{6} \mathrm{AS}_{3} \mathrm{H}_{12}\right)
$$

Combining with Equation 6 and Equation 9, 1 mol of $\mathrm{C}(\mathrm{B})_{4} \mathrm{~A}_{3} \breve{\mathrm{S}}$ equivalently reacts with $2 \mathrm{~mol}$ of $\mathrm{C}_{3} \mathrm{~A}$. So, $7 \mathrm{~g}$ of $\mathrm{C}(\mathrm{B})_{4} \mathrm{~A}_{3} \mathrm{~S}$ reacts $7 \times(270.2 \times 2) / 731.79=5.17 \mathrm{~g}$ $\mathrm{C}_{3} \mathrm{~A}$ per $100 \mathrm{~g}$ of SWPC clinker.

Therefore, in case of excessive CŠ affecting setting time and stability, in paper $8 \%$ and $10 \%$ of CŠ were selected and the cement samples are recorded as SWPC8 and SWPC10, respectively.

\section{EXPERIMENTAL}

\section{Scanning electron microscopy}

A Hitachi S-2500-scanning electron microscopy was used to analyze the microstructure of the hardened cement paste. Specimens were fractured and the internal small pieces were selected as the samples. After termination of sample hydration with alcohol, the samples were dried in vacuum at $70^{\circ} \mathrm{C}$. Then they were affixed to the scanning electron microscope specimen holder with epoxy resin. Specimens then were coated with a very thin layer of gold to promote electrical conductivity.

\section{Compressive strength}

The compressive strength of pastes was tested at $1,3,7$, and 28 days in accordance with GB T176711999. Each compressive strength value was the average of three samples. Three cubic samples, with size of

Table 3. The basic physical properties of SMPC.

\begin{tabular}{lccccc}
\hline Sample & $\begin{array}{c}\text { Specific surface } \\
\text { Blaine }\left(\mathrm{m}^{2} \cdot \mathrm{kg}^{-1}\right)\end{array}$ & $\begin{array}{c}\mathrm{f}-\mathrm{CaO} \\
(\%)\end{array}$ & \multicolumn{2}{c}{ Setting time (min) } & $\begin{array}{c}\text { Water } \\
\text { demand }\end{array}$ \\
\hline PC & 380 & 0.72 & 120 & 200 & 0.29 \\
SMPC8 & 382 & 0.34 & 60 & 121 & 0.32 \\
SMPC10 & 397 & 0.33 & 65 & 130 & 0.33 \\
\hline
\end{tabular}

$40 \times 40 \times 160 \mathrm{~mm}^{3}$, were used for each age. The specimens produced from fresh mortar were demoulded after $24 \mathrm{~h}$ with $20 \pm 2^{\circ} \mathrm{C}$ and $95 \%$ relative humidity, and were then cured in water with the temperature of $20 \pm 2{ }^{\circ} \mathrm{C}$ until the specimens were then used for compressive strength tests at $1,3,7$, and 28 days.

\section{RESULTS AND DISCUSSION}

\section{Physical properties of SMPC}

SMPC was prepared by mixing SMPC clinker with $10 \%$ gypsum. The basic physical properties of SMPC were shown in Table 3 . The setting time of SMPC was in line with the requirement in Chinese Standard GB175-2007 for ordinary PC. But compared with PC, initial and final setting time was obviously short. It was attributed to the existence of $\mathrm{C}_{2.75} \mathrm{~B}_{1.25} \mathrm{~A}_{3} \mathrm{~S}$ and the mineralization of $\mathrm{SO}_{3}$ and $\mathrm{BaO}$. Normally the water required for standard consistency of $\mathrm{PC}$ was in a range of $0.25-0.30$ [20]. The water demand for standard consistency of SMPC was higher than that of PC, which could be mainly attributed to loose surface structure of sulphoaluminate mineral particles and more gel water of ettringite $\left(3 \mathrm{CaO} \cdot \mathrm{Al}_{2} \mathrm{O}_{3} \cdot 3 \mathrm{CaSO}_{4} \cdot 32 \mathrm{H}_{2} \mathrm{O}\right)$ than $\mathrm{C}-\mathrm{S}-\mathrm{H}$ as the hydrating product. It can be inferred that the basic physical properties of SMPC are similar to that of PC and the former could to some extent replace the latter.

\section{Pore structure analysis of hydrating pastes}

Pore structures of hydrating pastes cured for 3 days and 28 days were shown in Table 4 . The porosity values of both SMPC pastes and PC pastes reduced significantly with curing time increasing. It indicated that the hydration reactions went on and hydration products gradually filled the pores, especially with a diameter of $>100 \mathrm{~nm}$. And compared with PC pastes at the same curing time, the pore size of SMPC pastes was smaller. The harmful pores content with a diameter of $>50 \mathrm{~nm}$ in SMPC8 paste was $76.1 \%$ which was $5.5 \%$ less than PC cured for 3 days. The harmful pores content with a diameter of $>50 \mathrm{~nm}$ in SMPC10 paste was $74.7 \%$ which was $6.9 \%$ less than PC cured for 3 days.

Table 4. Pore structure analysis of the pastes.

\begin{tabular}{lccccccc}
\hline Sample No. & $\begin{array}{c}\text { Curing } \\
\text { time (d) }\end{array}$ & $\begin{array}{c}\text { Most possible } \\
\text { aperture }(\mathrm{nm})\end{array}$ & $\begin{array}{c}\text { Porosity } \\
(\%)\end{array}$ & \multicolumn{4}{c}{ Pore diameter distribution (\%) } \\
\cline { 5 - 9 } PC & 3 & 6.8 & 37.7 & 6.9 & 11.5 & 30.2 & 51.4 \\
\hline \multirow{2}{*}{ SMPC8 } & 28 & 5.4 & 18.2 & 16.4 & 26.2 & 33.1 & 24.3 \\
\hline \multirow{2}{*}{ SMPC10 } & 3 & 6.6 & 36.7 & 8.2 & 15.7 & 32.1 & 44.0 \\
& 28 & 5.3 & 14.9 & 17.2 & 23.1 & 35.7 & 24.0 \\
\hline
\end{tabular}


The percentage of harmful pores in SMPC8 paste was $59.7 \%$ which was $7.7 \%$ less than PC cured for 28 days. The percentage of harmful pores in SMPC10 paste was $54.3 \%$ which was $13.1 \%$ less than PC cured for 28 days.

\section{SEM-EDS analysis of hydrating products}

The microstructures of the SMPC10 and PC pastes hydrating at 3 days were shown in Figure 2. At the age of 3 days, paste structure was relatively loose. A large amount of unhydrated particles were left. Hydration products were presented by the reticulated $\mathrm{C}-\mathrm{S}-\mathrm{H}$ gel coating on the surface of the grains and the needle-shaped ettringite crystals, resulting in a dense structure and low porosity. Crystallized $\mathrm{Ca}(\mathrm{OH})_{2}$ could not be found in SEM observation of SMPC paste, which resulted from that $\mathrm{C}_{2.75} \mathrm{~B}_{1.25} \mathrm{~A}_{3} \breve{\mathrm{S}}$ reacted with $\mathrm{Ca}(\mathrm{OH})_{2}$ generated during $\mathrm{C}_{3} \mathrm{~S}$ hydrating to delay the precipitation of crystallized $\mathrm{Ca}(\mathrm{OH})_{2}$.

Equations 10-13 showed the common hydration reactions of $\mathrm{C}_{2.75} \mathrm{~B}_{1.25} \mathrm{~A}_{3} \check{\mathrm{S}}$ in SMPC.

$$
\mathrm{CS}+2 \mathrm{H} \rightarrow \mathrm{CS}^{\mathrm{S}} \mathrm{H}_{2}
$$

$$
\mathrm{C}(\mathrm{B})_{4} \mathrm{~A}_{3} \check{\mathrm{S}}+2 \mathrm{CŠH}_{2}+34 \mathrm{H} \rightarrow(\mathrm{B})_{6} \mathrm{AS}_{3} \mathrm{H}_{32}+2 \mathrm{AH}_{3}
$$$$
\mathrm{C}(\mathrm{B})_{4} \mathrm{~A}_{3} \check{\mathrm{S}}+8 \mathrm{CS}^{\mathrm{S}} \mathrm{H}_{2}+6 \mathrm{CH}+74 \mathrm{H} \rightarrow 3 \mathrm{C}(\mathrm{B})_{6} \mathrm{AS}_{3} \mathrm{H}_{32}
$$

$$
\mathrm{AH}_{3}+3 \mathrm{CH}+3 \mathrm{CřH}_{2}+20 \mathrm{H} \rightarrow \mathrm{C}_{6} \mathrm{AS}_{3} \mathrm{H}_{32}
$$
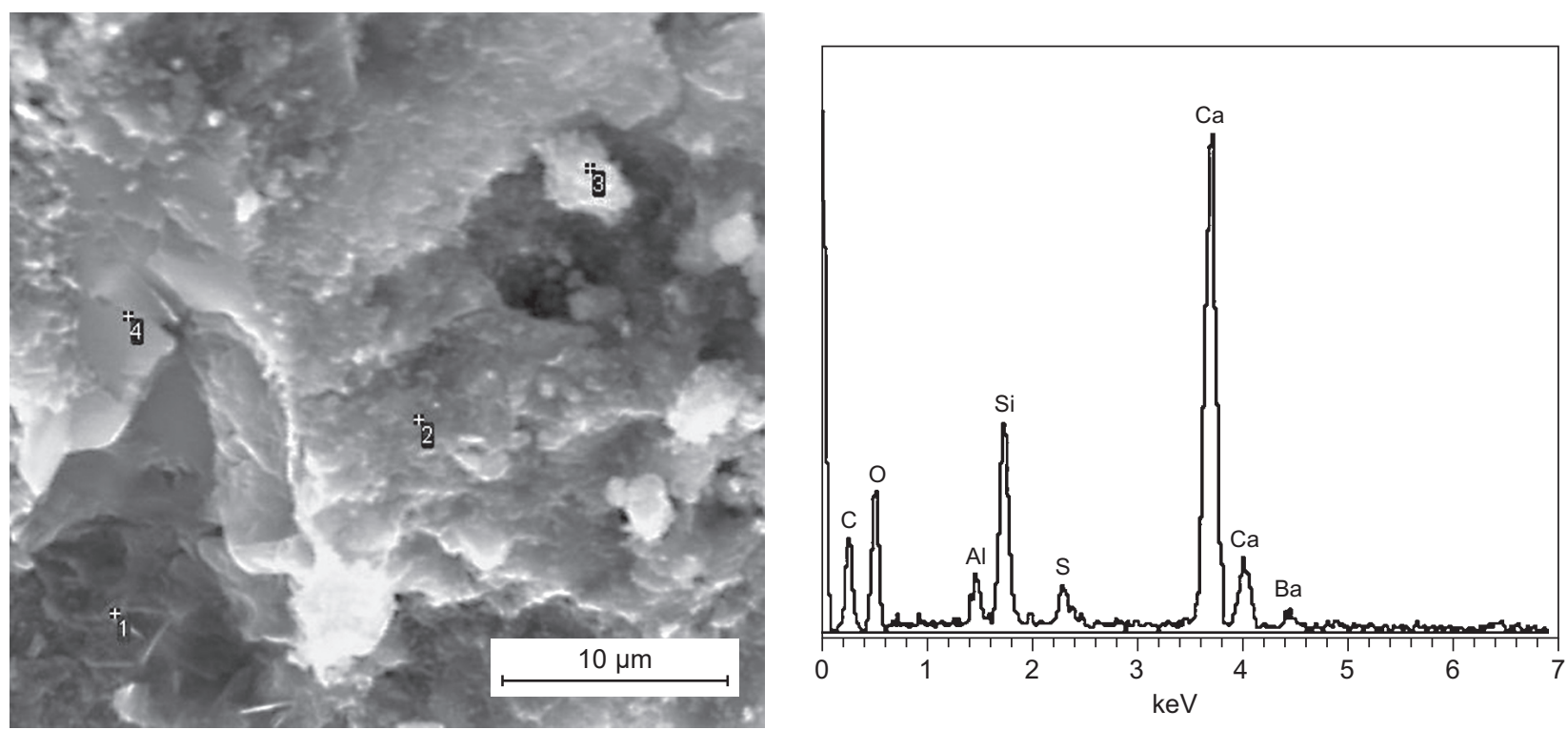

a) SMPC10 hydrating for 3 days
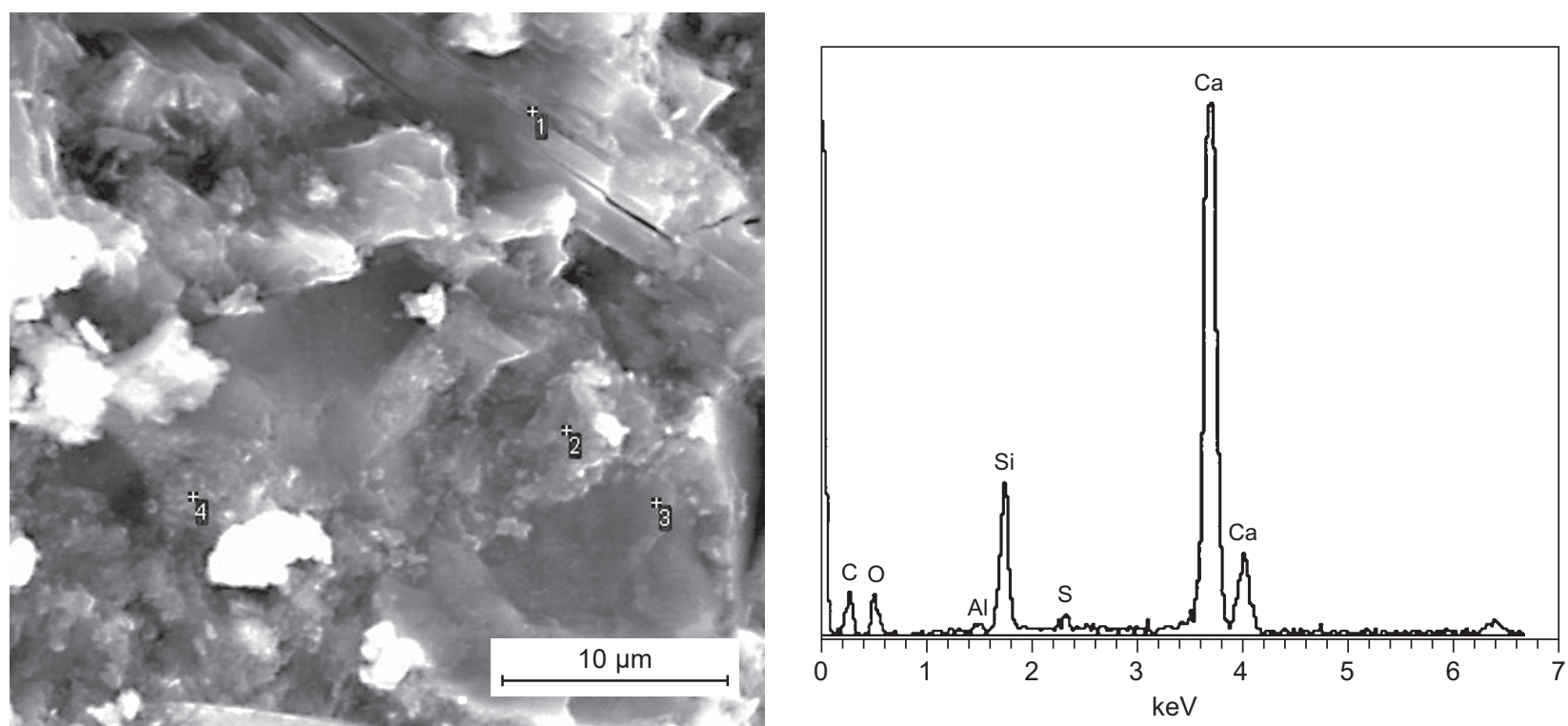

b) PC hydrating for 3 days

Figure 2. SEM-EDS photographs of cement pastes at 3 days. 

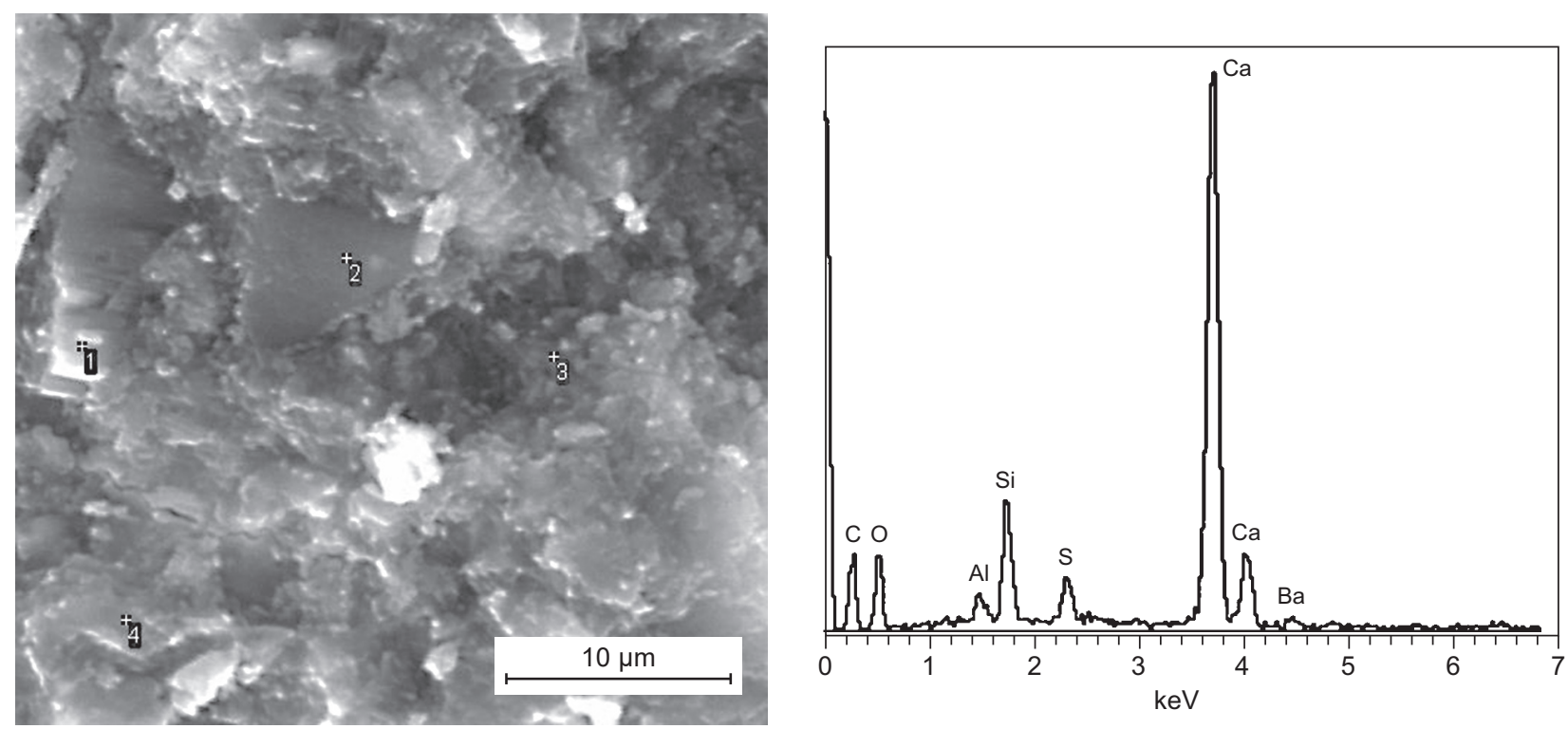

a) SMPC10 hydrating for 28 days
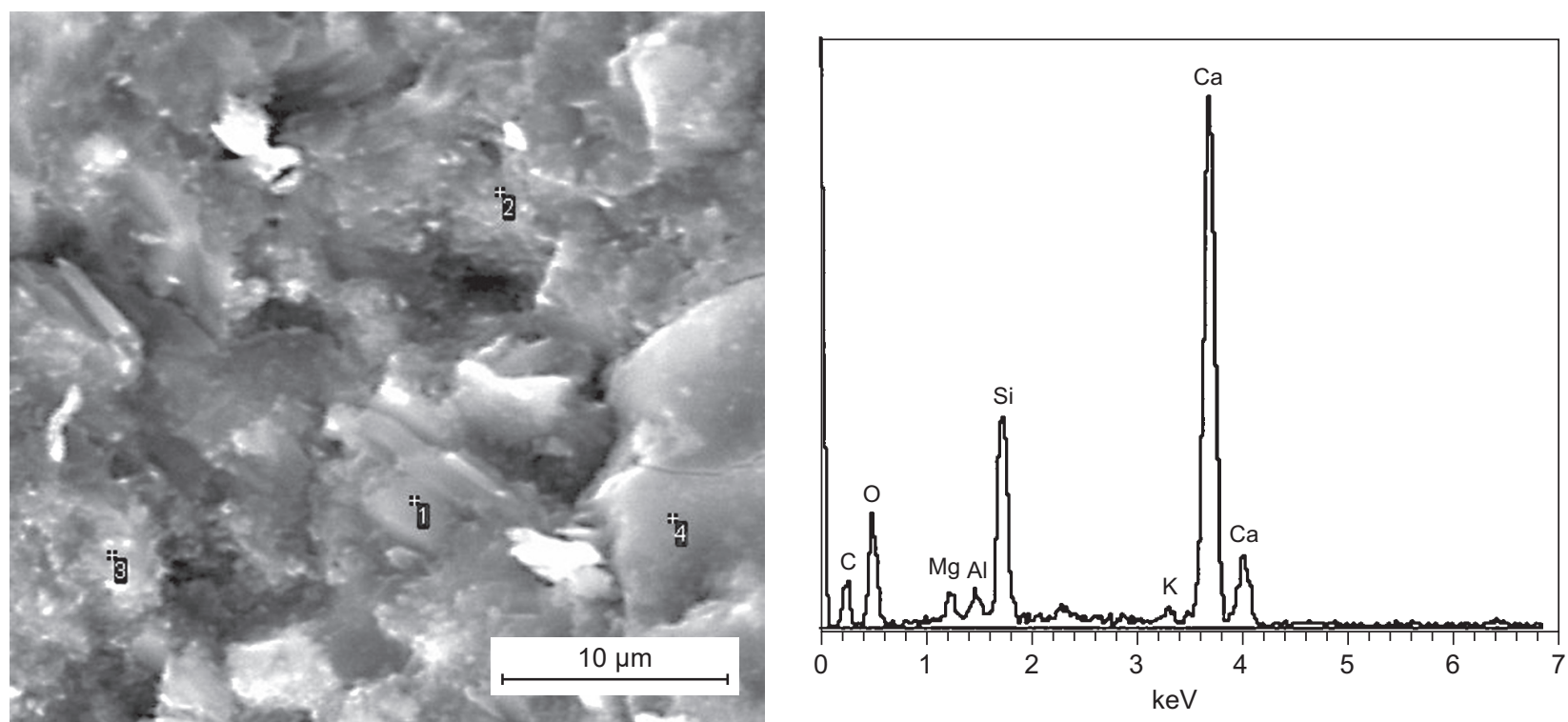

b) PC hydrating for 28 days

Figure 3. SEM-EDS photographs of cement pastes hydrating for 28 days.

The microstructures of the SMPC and PC pastes hydrated at 28 days were shown in Figure 3. At the age of 28 days, it was noted that the hardened SMPC and PC pastes were compact and continued integrated morphological characteristics. Unhydrated particles were partially covered by thick and dense hydration products. Comparing SMPC and PC pastes, the latter structure was relatively loose, which was consistent with the results in Table 4. And $\mathrm{CH}$ crystal was visible. SMPC paste alkalinity was lower, which was beneficial to excellent durability and corrosion resistance.

EDS pattern of SMPC paste cured for 3 days and 28 days showed that ettringite bearing $\mathrm{Ba}$ was early hydration product and existed stably in the pastes. It indicated that $\mathrm{Ba}^{2+}$ went into the network skeleton of sulphoaluminate minerals, which was consistent with XRD analysis in Figure 1.

\section{Expansibility analysis of hydrating pastes}

The expansibility analysis of hydrating pastes of SWPC and PC were shown in Figure 4. Compared to PC, the expansion ratios of SWPC8 and SWPC10 are higher than those of PC samples, which is attributed to much more AFt during SWPC hydrating. 31 - 32 water molecules are combined in the process of AFt formation, including 6 lattice firmly bound water molecules and 26 coordination water molecules, which makes $\mathrm{AFt}$ solid-phase volume increasing by about $125 \%$. And at 
the same time, in the process of hydration hardening, due to crystallization and water absorption expansion deformation under the constraint condition into the cement compressive stress, tensile deformation has been better.

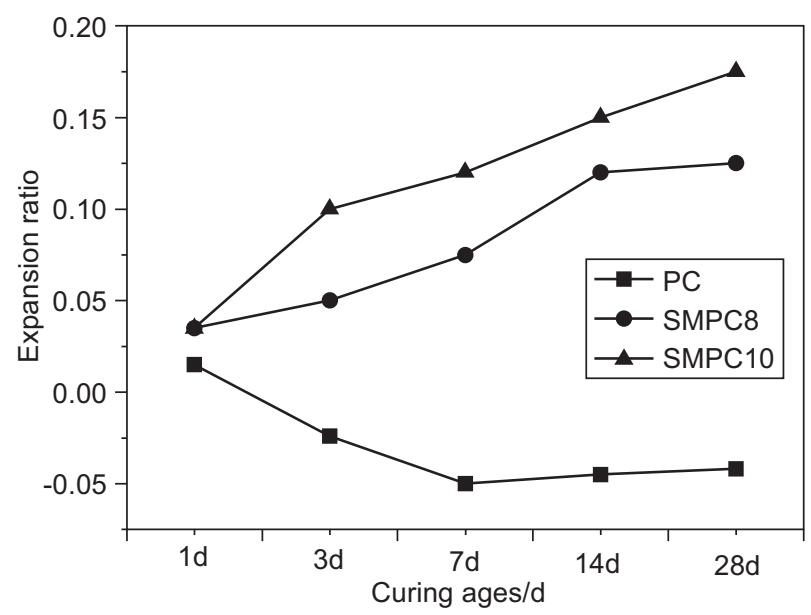

Figure 4. Expansion ratios of cements at different curing ages.

\section{Compressive strength of SMPC}

The compressive strengths of SMPC8, SMPC10 and $\mathrm{PC}$ were shown in Figure 5. PC was used as the reference sample in the test of strength development. The compressive strengths of SMPC8 and SMPC10 pastes cured for $1,3,7$ and 28 days were higher than those of PC respectively. Especially the compressive strengths of SMPC8 and SMPC10 grew faster than PC at the early curing ages. The strengths of the SMPC8 and SMPC10 pastes cured for 1day were $15.4 \%$ and $9.5 \%$ higher than PC respectively. The strengths of the SMPC8 and SMPC10 pastes cured for 3days were $28.6 \%$ and $31.4 \%$ higher than PC respectively. The strengths of the SMPC8 and SMPC10 pastes cured for 7 days were $17.5 \%$ and $20.2 \%$ higher than PC respectively. It was indicated that sulfur aluminum barium calcium was a new early-strength mineral [21] and its hydration speed and contribution to the strength was superior to $C_{3} S$, so

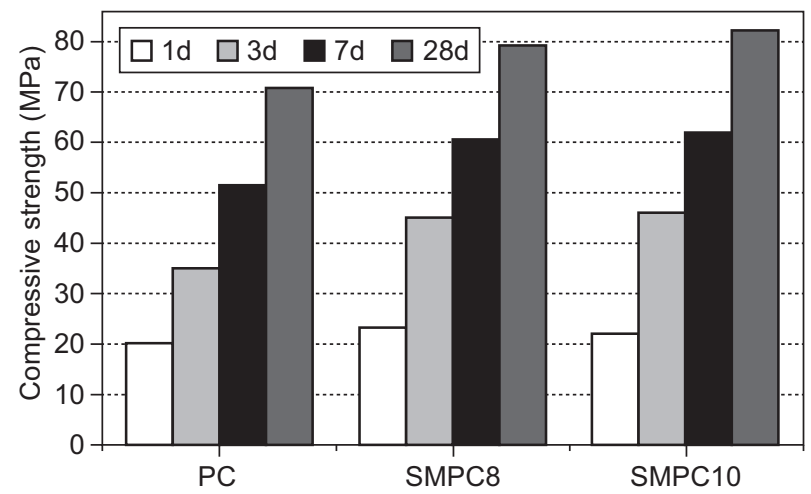

Figure 5. Compressive strength of cements at different curing temperatures.
SMPC8 and SMPC10 had higher hydration speed and compressive strength.

The strengths of the SMPC8 and SMPC10 pastes cured for 28days were $11.7 \%$ and $15.9 \%$ higher than PC respectively. During sintering SMPC clinker parts of $\mathrm{BaO}$ went into the $\mathrm{C}_{2} \mathrm{~S}$ lattice and caused lattice distortion, which could enhance $\mathrm{C}_{2} \mathrm{~S}$ hydration activity [22-24]. Therefore, the compressive strength of SMPC was superior to $\mathrm{PC}$ even at the late curing age.

\section{CONCLUSIONS}

- Basic physical properties of modified Portland cement with Ba-bearing sulphoaluminate minerals with $\mathrm{C}_{3} \mathrm{~S}$, $\mathrm{C}_{2} \mathrm{~S}, \mathrm{C}_{4} \mathrm{AF}, \mathrm{C}_{3} \mathrm{~A}$ and $\mathrm{C}_{2.75} \mathrm{~B}_{1.25} \mathrm{~A}_{3} \breve{\mathrm{S}}$ as the main phases are similar with $\mathrm{PC}$, except that the setting time including initial time and final time is shorter.

- Ettringite and $\mathrm{C}-\mathrm{S}-\mathrm{H}$ are the main hydrating produces in SMPC, which is similar to PC. Because of volume expansion of ettringite, SMPC paste structure is denser than PC according to SEM-EDS analysis and the pore size of SMPC pastes was smaller. The harmful pores content with a diameter of $>50 \mathrm{~nm}$ in SMPC8 and SMPC10 was $5.5 \%$ and $6.9 \%$ less than PC cured for 3 days. The percentage of harmful pores in SMPC8 and SMPC10 was $7.7 \%$ and $13.1 \%$ less than PC cured for 28 days.

- Because sulfur aluminum barium calcium was a new early-strength mineral and its hydration speed and contribution to the strength was superior to $\mathrm{C}_{3} \mathrm{~S}$, the compressive strengths of SMPC8 and SMPC10 grew faster than PC at the early curing ages. During sintering SMPC clinker parts of $\mathrm{BaO}$ went into the $\mathrm{C}_{2} \mathrm{~S}$ lattice and caused lattice distortion to enhance $\mathrm{C}_{2} \mathrm{~S}$ hydration activity, the strengths of the SMPC8 and SMPC10 pastes cured for 28days were $11.7 \%$ and $15.9 \%$ higher than PC respectively.

\section{Acknowledgments}

This work is supported by Natural Science Foundation of China (No. 51302104 and No.51472109).

\section{REFERENCES}

1. Mehta P.K. (2002): Greening of the concrete industry for sustainable development. Concrete International, 24(7), 23-28.

2. Sharp J.H., Lawrence C.D., Yang R. (1999): Calcium sulfoaluminate cements - low-energy cements, special cements or what? Advances in Cement Research, 11, 3-13. doi:10.1680/adcr.1999.11.1.3

3. Keith Q. (2001): Performance of belite-sulfoaluminate cements. Cement and Concrete Research, 31(9), 1341-1349. doi:10.1016/S0008-8846(01)00543-9

4. Damtoft J.S., Lukasik J., Herfort D., Sorrentino D., Gartner 
E.M. (2008): Sustainable development and climate change initiatives. Cement and Concrete Research, 38(2),115-127. doi:10.1016/j.cemconres.2007.09.008

5. Gartner E. (2004): Industrially interesting approaches to "low $\mathrm{CO}_{2}$ " cements. Cement and Concrete Research, 34(9), 1489-1498. doi:10.1016/j.cemconres.2004.01.021

6. Martín-Sedeño M.C., Cuberos A. J., Ángeles G., ÁlvarezPinazo G., Ordónez L.M., Gateshki M., Aranda M.A. (2010): Aluminum-rich belite sulfoaluminate cements: Clinkering and early age hydration. Cement and Concrete Research, 40(3), 359-369. doi:10.1016/j.cemconres.2009.11.003

7. Chatterjee A.K. (1996): High belite cements. Present status and future technological options: Part I and Part II. Cement and Concrete Research, 26(8), 1213-1225, 1227-1237. doi: 10.1016/0008-8846(96)00099-3; doi:10.1016/00088846(96)00100-7

8. Popescu C.D., Muntean M., Sharp J.H. (2003): Industrial trial production of low energy belite cement. Cement and Concrete Composites, 25(7), 689-693. doi:10.1016/S09589465(02)00097-5

9. Glasser F.P., Zhang L. (2001): High-performance cement matrices based on calcium sulfoaluminate-belite compositions. Cement and Concrete Research, 31(12), 1881-1886. doi:10.1016/S0008-8846(01)00649-4

10. Chen Y.L., Shih P.H., Chiang L.C., Chang Y.K., Lu H.C., Chang J.E. (2009): The influence of heavy metals on the polymorphs of dicalcium silicate in the belite-rich clinkers produced from electroplating sludge. Journal of Hazardous Materials, 170(1), 443-448. doi:10.1016/j. jhazmat.2009.04.076

11. Kacimi L., Simon-Masseron A., Salem S., Ghomari A., Derriche Z. (2009): Synthesis of belite cement clinker of high hydraulic reactivity Cement and Concrete Research, 39(7): 559-565. doi:10.1016/j.cemconres.2009.02.004

12. Ali M.M., Gopal S., Handoo S.K. (1994): Studies on the formation kinetics of calcium sulfoaluminate. Cement and Concrete Research, 24(4), 715-720. doi:10.1016/00088846(94)90196-1

13. Janotka I, Krajči L',, Ray A., Mojumdar S.C. (2003): The hydration phase and pore structure formation in the blends of sulfoaluminate-belite cement with Portland cement. Cement and Concrete Research, 33(4), 489-497. doi:10.1016/S0008-8846(02)00994-8

14. Pliego-Cuervo Y.B., Glasser F.P. (1979): The role of sulphates in cement clinkering: subsolidus phase relations in the system $\mathrm{CaO}-\mathrm{Al}_{2} \mathrm{O}_{3}-\mathrm{SiO}_{2}-\mathrm{SO}_{3}$, Cement and Concrete Research, 9(1), 51-56. doi:10.1016/0008-8846(79)90094-2

15. Arjunan P., Silsbee M.R., Roy D.M. (1999): Sulfoaluminate-belite cement from low-calcium fly ash and sulfur-rich and other industrial by-products, Cement and Concrete Research, 29(8), 1305-1311. doi:10.1016/S00088846(99)00072-1

16. Li H., Agrawal D.K., Cheng J., Silsbee M.R. (2001): Microwave sintering of sulphoaluminate cement with utility wastes, Cement and Concrete Research, 31(9), 12571261. doi:10.1016/S0008-8846(01)00579-8

17. Zhang L., Glasser F.P. (2002): Hydration of calcium sulfoaluminate cement at less than $24 \mathrm{~h}$. Advances in cement research, 14(4), 141-155. doi:10.1680/adcr.2002.14.4.141

18. Popescu C.D., Muntean M., Sharp J.H. (2003): Industrial trial production of low energy belite cement, Cement and Concrete Composites, 2003; 25(7): 689-693. doi:10.1016/ S0958-9465(02)00097-5

19. Teoreanu I., Muntean M., Dragnea I. (1986): Type $3(\mathrm{CaO} \cdot \mathrm{Al} 2 \mathrm{O} 3) \cdot \mathrm{Mx}(\mathrm{SO} 4) \mathrm{y}$ compounds and compatibility relations in $\mathrm{CaO}-\mathrm{CaO} \cdot \mathrm{Al} 2 \mathrm{O} 3-\mathrm{Mx}(\mathrm{SO} 4) \mathrm{y}$ systems. Cement, 83(1), 39-45.

20. Yan P. (1993) Hydration of Sr- and BA-bearing sulphoaluminates in the presence of sulphates. Advances in cement research, 18(5), 65-69. doi:10.1680/adcr.1993.5.18.65

21. Wang S., Huang Y., Gong C., Lu L., Cheng, X. (2014): Formation mechanism of barium calcium sulfoaluminate mineral. Advances in Cement Research, 26(3): 169-176. doi:10.1680/adcr.13.00016

22. Morsli K., De La Torre Á.G., Stöber S., Cuberos A.J., Zahir M., Aranda, M.A. (2007): Quantitative phase analysis of laboratory active belite clinkers by synchrotron powder diff-raction. Journal of the American Ceramic Society, 90(10), 3205-3212. doi:10.1111/j.1551-2916.2007.01870.x

23. Zhao Y., Lu L., Wang S., Gong C., Huang, Y. (2013): Modification of dicalcium silicates phase composition by $\mathrm{BaO}, \mathrm{SO}_{3}$ and $\mathrm{MgO}$. Journal of Inorganic and Organometallic Polymers and Materials, 23(4), 930-936. doi:10.1007/s10904-013-9873-2

24. Kim Y.M., Hong S.H. (2004): Influence of minor ions on the stability and hydration rates of $\beta$-dicalcium silicate. Journal of the American Ceramic Society, 87(5), 900-905. doi:10.1111/j.1551-2916.2004.00900.x 